\title{
Az Állattani Szakosztály ülései (2016. február 3. - 2016. december 7.)
}

\author{
AngYal DorotTya $^{1^{*}}$ és Nagy PÉTeR ${ }^{2}$ \\ ${ }^{1}$ Magyar Természettudományi Múzeum Állattára, 1088 Budapest, Baross u. 13. \\ E-mail: angyal.dorottya@gmail.com \\ ${ }^{2}$ Szent István Egyetem, Mezőgazdaság- és Környezettudományi Kar, \\ Állattani és Állatökológiai Tanszék, 2100 Gödöllő, Páter K. u. 1.
}

1029. előadóülés, 2016. február 3-án

Az ülést NAGY PÉTER elnök úr nyitotta meg, aki köszöntötte az új szakosztályi évad első előadóülésén megjelenteket.

1. Péntek Attila, Horváth Zsófia, Tóth Adrienn, Cozma Nastasia Julianna, Földi Angéla, Böde Nóra Anita, Zsuga Katalin, Móra ARnold, Tóth Bence, ROBERT PTACNIK, ÁCs ÉVA és HORNUNG ERZSÉBET: Az apaji bombatölcsérekben kialakult szikes kisvizek természetvédelmi jelentősége.

A bombatölcsérek széles körben elterjedtek. Általában több, egymáshoz közeli mikroélőhelyként szolgáló víztestek, Magyarországon is több ezer ilyen fordul elő, elsősorban a Hortobágyon és a Kiskunságban, bár az előbbi helyen nagyrészt már felszámolták ezeket. A szikes tavak köztudottan speciális élőhelyek. Az apaji bombatölcsérek sok tekintetben hasonlóak a fokozottan védett szikes tavakhoz. Nagy valószínüséggel az 1940-es években keletkeztek a kiskunlacházi német katonai reptér bombázása következtében. 112 kráter keletkezett egy 25 hektáros területen, ami elsődlegesen (a folyószabályozásokat megelőzően) hasonló, nedves terület volt. Ezek magas, pH 8-12 közötti sótartalommal és különböző turbiditási-, átmérő- és vegetációs viszonyokkal rendelkeznek. A kutatások célcsoportjai a kisvizek ,zászlóshajófajai” voltak: kétéltüek, tócsarákok, szitakötők, valamint zooplankton, kisrákok, kerekesférgek, bogarak, poloskák, árvaszúnyogok és kovaalgák. Hat alkalommal végeztek mintavételezéseket 2014 és 2015 során. Vizuális szemlézést, illetve kishálókat alkalmaztak. A tócsarákokat 2014 során két alkalommal gyüjtötték, míg a többi csoportot „kampányszerüen”. Kétéltüek közül 7 taxont találtak, ezek többnyire gyakori fajok voltak, de zöld varangy és pettyes gőte csak 1-1 példányban fordult elő. A leggyakoribb kétéltü a vöröshasú unka volt, míg a legértékesebb a dunai tarajosgőte (Triturus dobrogicus). Szaporodó fajokként a zöld levelibéka, a barna ásóbéka, az unkák (két színváltozat) és a „zöld békák” (Rana/Pelophylax fajok) fordultak elö. Szaporodásukat a jelek szerint nem zavarták az extrém körülmények. A hüllők közül előfordult a mocsári teknős: a terület jó fészkelő helyeket nyújtott számukra. Néhány példány vízisikló jelenlétét is észlelték. A tócsarákok (Anostraca) közül előfordult néhány különlegesebb faj, mint például a 
Chirocephalus carnuntanus. A makrogerinctelenek közül a legtöbb faj a bogarak, a szitakötők és poloskák közé tartozott. A megtalált Brachionus asplanchnoides kerekesféreg faj világszerte ritka, és sós vízhez kötődik. A kisrákok közül jelen volt az Arctodiaptomus spinosus, a szikes tavak indikátorfaja. A kovaalgák két világszerte ritka, veszélyeztetett taxonja is elökerült, csakúgy, mint egy dél-amerikai előfordulású faj. Béta-diverzitás (SDR simplex analízis) során azt kapták, hogy a fajhelyettesítés volt a legfontosabb komponens. Nagy különbségeket kaptak az egyes kisvizek páronkénti összehasonlítása során. Nagyfokú volt a mozaikosság, ez sokféle élőhelyi feltételrendszer jelenlétére utal. Összefoglalásként Előadó elmondta, hogy sok veszélyeztetett, ritka és endemikus faj jelenlétét mutatták ki a bombatölcsérekben. Nagyfokú „regionális diverzitás” volt jellemzö. A legsósabb vizekben fordult elő a legkevesebb faj, de ezekben voltak a legértékesebb közösségek. Ezek az élőhelyek kiváló modelljei lehetnek későbbi ökológiai kutatásoknak. Az előadás után JÁNOSI LÁszLó azt a kérdést tette fel, hogy megtalálták-e a tavaszi vagy nyári pajzsosrákot a területen. A válasz szerint ezeket a fajokat nem sikerült kimutatni. SERFÖZÖ ZOLTÁN: Van-e valamilyen dinamikája a víz nélküli időszak átvészelésére irányuló törekvéseknek? Hol vészelik át a kedvezötlen időszakokat? A válasz szerint különböző mértékủ, jellegű megoldások lehetségesek erre vonatkozóan. A kétéltüek például áthúzódhatnak halastavakba.

2. SARLÓs DÁVID, BoltizÁr OtTó és HegYi ÁRPÁD: A Rákos-patak egyes szakaszainak halfaunisztikai vizsgálata.

Az ezredforduló óta dokumentált vizsgálatok során, összehasonlítható módszerekkel elvégzett mintavételezés eredményeként 16 halfaj 925 egyedét sikerült kimutatni. Az előadás ezek különféle ökológiai szempontok szerinti csoportosításával is foglalkozott. A leggyakoribb fajok a kínai razbóra (51\%), a tarka géb (22\%), az ezüstkárász (12\%), a vágó csík (3\%) és a fenékjáró küllő (2\%). Egyik fontos védett faj a szivárványos ökle, mely újdonságnak számít: a Rákos-patak nem tipikus élőhely számára. Előadó érdekességként említette, hogy a fenékjáró küllő kikövezett szakaszokon fordult elő, míg a vágó csík a kőbányai, hordalékosabb medrủ szakaszon volt jelen. Előadó javaslata szerint a legfontosabb a patak ökológiai állapotának védelme lenne. Bármerre jártak a vizsgálat alatt, mindenhol nagyon szemetes volt a patak és környezete. Érdemes lenne megőrizni az eddig ki nem betonozott szakaszok természeteshez közeli állapotát. Fontos lenne a mesterséges „gátak” megszüntetése, az invazív fajok számának csökkentése és patakba való bejutásuk megakadályozása (például a Gödöllő melletti halastavakból). Mindezek figyelembe vételével lenne lehetöség a fauna megőrzésére. JÁNOSI LÁSZLÓ az iránt érdeklődött, hogy a fajok képesek-e szabadon bevándorolni a Dunából, vagy van-e valamilyen akadálya ennek? A válasz szerint nincsen különösebb akadály, magasabb vízállásnál a halak be tudnak úszni. SERFÖZÖ ZOLTÁN javaslata szerint érdemes lenne regionális térképekkel szemléltetni az invazív fajok mozgását, terjedésük gátjait. KERESZTESSY KATALIN kiemelte a tógazdaságok szerepét az invazív, illetve élőhelyidegen fajok bekerülésében, valamint megemlített néhány, az ezredforduló előtt dokumentált érdekesebb fajelőfordulást a Rákos-patakból.

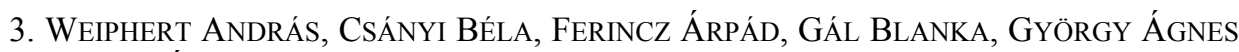
IRMA, HARKA ÁKOS, KERESZTESSY KATALIN, KOVÁCS KRISZTIÁN, LŐKKÖS ANDOR, MAÁSZ

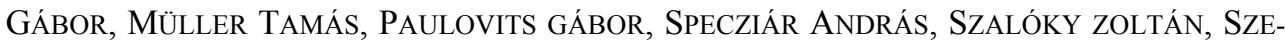

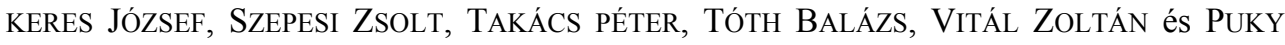
MILós †े: Gazdasági lehetőség, vagy inváziós veszélyforrás? Egzotikus élőlények hazánk vizeiben. 
A termálvízforrások a leginkább átalakított vizes élőhelyek közé tartoznak: ez is indokolja vizsgálatuk szükségességét. Hazánk fokozottan bővíteni kívánja a termálvizekben rejlő (gazdasági) lehetőségeket, azonban nem tisztázott, hogy mi történik a felszínre hozott vízzel. Ezen kívül is számítani kell az ipari melegvíz kibocsátás növekedésével. Európa természetes vizeiben az utóbbi évtizedekben jelentősen megszaporodott egyes egzotikus (pl. az akvaristák által kedvelt) fajok száma, illetve szándékosan behurcolt fajokról is tudomásunk van, mint például a szúnyogirtó fogasponty, ami képes már áttelelni hazai körülmények között is. Hazánk természetes vizeiböl is egyre többször írnak le egzotikus halfajokat. Akvarista honlapokról is lehet új információkat szerezni fajok észleléséről, esetleg azok betelepítőiről is. Az endemikus fajok rendszerint fokozottan érzékenyek az ilyesmire. A fekete bödöncsigának például összesen csak négy állománya ismert világszerte. Ebből kettő Ausztriában, egy Szlovéniában és egy hazánkban, Kácson van. Számos egzotikus fajt ismerünk már hazai vizeinkből, mint például a maláj toronycsigát a Városligeti tóból. A szúnyogirtó fogasponty már tartósan megtelepedett a Zagyvában. Sok első hazai, illetve Kárpát-medencei előfordulási adat betelepített fajokkal függ össze, mint amilyen a bölcsőszájú halakhoz tartozó Garra rufa ,pedikürös” hal, vagy a gombafertőzést terjesztő törpe karmosbéka. A vörös mocsárrák eredetileg a Karib-szigetekről ismert. Mélyre beásva magát képes hazánkban is áttelelni. Ma már ez a faj a hatodik ismert Decapoda faj Magyarországon. A márványrák képes partenogenetikusan szaporodni, ennek következtében rendkívül gyorsan terjed. A Hévízi-tó jelentős tündérrózsa pusztítása is ezzel a fajjal hozható összefüggésbe. Mindkét említett faj terjeszti a rákpestist, de önmaguk immunisak rá. A Hévízi-tóban rengeteg sügérféle (pl. jaguársügér) található. Említésre méltó az akváriumi díszhalak „karrierje”: elterjedt az amurgéb és a naphal. Ezek ma már hatalmas problémákat okoznak: előbbi nagyon gyorsan terjed, és neki róható fel a lápi póc eltünése bizonyos területekröl, illetve egyes kétéltüfajok állományának veszélyeztetése is. Végül Előadó felhívta a figyelmet az akvaristák hatalmas felelősségére és a jövőbeni kutatások fontosságára, valamint a tervezett beruházások esetén a felhasznált termálvíz minél nagyobb arányban történő visszasajtolásának fontosságára (amelynek kötelmét a jelenleg érvényes jogszabályok nem tartalmazzák). Az előadást élénk eszmecsere zárta, melynek keretében többen érdeklődtek egyes fajok elöfordulási helyei, illetve a problémák kezelésének technikai, valamint jogi aspektusai iránt. Az Előadó ezekre részletes válaszokat adott. Ezt követően az érdeklődők megszemlélhették egyes invazív fajoknak Előadó által hozott példányait.

\section{0. előadóülés, 2016. március 2-án}

Az ülést NAGY PÉTER elnök úr nyitotta meg és vezette le.

1. Derbák DÁvid, CSONKa DiÁnA, DÁnYi LÁszló és Hornung ERZséBet: $A$ Mesoniscus graniger (Frivaldszky, 1865) barlangi ászkafaj biológiája.

A Mesoniscus graniger föként barlangokból ismert, azonban vannak talajfelszíni adatai is. Troglomorf bélyegeket hordoz. Magyar elnevezését („szemercsés vakászkarák”) kültakarójának jellegzetes felszíni képződményeiről kapta. Főként mészkőben kialakult barlangokból vannak adatai, Szlovákiától Romániáig. A faj elterjedése szempontjából kiemelkedő jelentőségü terület az Aggteleki-karszt, mivel a faj típusegyedei a Baradla-barlangból 
származtak. A korábbi kutatások a faj hőmérsékleti toleranciájának vizsgálatára, táplálékának összetételére, ökofiziológiájára, ontogenezisére és elterjedésére irányultak. Jelen kutatás célja a faj külső morfológiájának, az ovárium és a marsupium belső szerkezetének jobb megismerése volt. Tanulmányozták továbbá a faj fenológiáját, ezen belül a testméretet, a korcsoportok időbeli eloszlását és a populációk ivararányát. Egyes életmenet-összetevőket is vizsgáltak, mint a szaporodás időzítése és a szaporodási stratégia. A vizsgálathoz szlovákiai barlangokból és a Baradla-barlangból származó talajcsapda anyagot használták, valamint saját gyüjtésből (szintén a Baradla-barlangból) származó egyedeket. A Baradlabarlang Róka-ágában elhelyezett dobozokban tenyésztették is az állatokat. Pásztázó elektronmikroszkópia alkalmazásával sikerült megfigyelni, hogy a szemcsék a kültakarón szabályos sorokba rendeződnek. Fénymikroszkóp alatt készült fotón jól látszott a marsupium (megegyezett a szárazföldi ászkák marsupiumával), az ovarium és az oostegitek. Mérték a fej szélességét és azt az eredményt kapták, hogy különbség van e tekintetben a hímek és a nőstények között. Azt találták továbbá, hogy a manca mérete rendkívül nagy. További terveik között szerepel a populációméret változásának elemzése, újabb szövettani metszetek készítése, a morfológiai vizsgálatok folytatása és az adatok elemzése. NAGY PÉTER: A szemcsék összetételét, funkcióját illetően kiderült már esetleg valami? DERBÁK DÁVID: Valószínủleg az érzékelésben játszanak szerepet (páratartalom, vagy mechanikai hatások). NAGY PÉTER: Publikálták már az eredményeket? A válasz szerint ez tervben van. MERKL OTTÓ megkérdezte, mi is pontosan a „manca”. A válasz szerint fiatal lárva, ami 6 pár lábbal rendelkezik. SZÖVÉNYI GERGELY: Mennyire könnyen tarthatóak az állatok? DERBÁK DÁVID: Hütőszekrényben relatíve könnyen tarthatóak. SzÖVÉNYI GERGELY: Mivel etetik öket, guanóval? A válasz szerint igen, és a barlangból származó falevelekkel.

2. MolnÁr BAlÁZs, SZeréNyi GÁBOR és SZÖvéNyI Gergely: Az érdi Fundoklinavölgy faunisztikai kutatása.

Az előadás anyaga az Állattani Közlemények jelen kötetében olvasható.

3. TÓTH BALÁZS é s RONKAY LÁSZLÓ: Tudományra új karcsúbaglyok a Magyar Természettudományi Múzeum Lepkegyüjteményében (Lepidoptera: Erebidae, Hypeninae).

Előadó és munkatársa a Naarda WALKER, 1866 karcsúbagoly lepke génuszt tanulmányozták. Ez egy egységes csoport, a fajok nagyon hasonlóak egymáshoz. Általában kisméretüek, barna színezetủek zegzugos keresztvonalakkal tarkítva. Fejtetői pamaccsal és jól fejlett pödörnyelvvel rendelkeznek. Ennél a nemnél az imágó is táplálkozik. Az ivari kétalakúság főként a hímek illatpamacsaiban nyilvánul meg. A Naarda fajok jó vízellátottságú erdőkben élnek Nepál, Vietnam és Tajvan trópusi és szubtrópusi területein. A gyüjteményi anyag feldolgozása során nemrég számos tudományra új fajt sikerült leírni különböző ázsiai országokból. Az előadás folytatásában TóTH BALÁzS és RONKAY LÁszLó által a közelmúltban leírt fajok fotóit láthatjuk. Ezek a következők: a Fülöp-szigetekről és Thaiföldről ismert Naarda alternata TÓTH \& RONKAY, 2014, a N. hallasana TÓTH \& RONKAY, 2015, a $N$. cinerea TÓTH \& RONKAY, 2014, a macskaszemre emlékeztető szárnyfolttal rendelkező $N$. felinopsis, a kambodzsai $N$. bicolora TóTH \& RONKAY, 2015, a mézszínü $N$. melistigma TÓTH \& RONKAY, 2015, a thaiföldi $N$. ardeola TóTH \& RONKAY, 2014, mely nevét madár alakú hímivarszervéröl kapta, és a gyüjtőjéröl elnevezett $N$. pocstamasi TóTH \& RONKAY, 2014, melynek egyetlen példánya áll rendelkezésre. Összegzésként Előadó elmondta, hogy 63 ázsiai faj összesen 303 egyedével dolgoztak, ebből 48 faj újnak bizonyult. A Magyar 
Természettudományi Múzeum Lepkegyűjteménye 35 holotípussal gazdagodott. A továbbiakban az afrikai anyagok vizsgálatát szeretnék megkezdeni.

4. Horváth Gergely, José Martín, Pilar lópez, Garamszegi László Zsolt és HERCZEG GÁBOR: Hogy függ össze a bátorság az éhezéssel és a D-vitaminnal? Az Iberolacerta cyreni személyiségkutatás új eredményei.

Az állati személyiség az új nézőpont szerint az egyedek között megfigyelhető, konzisztens viselkedésbeli eltérés, mely akár már a gerincteleneknél is megfigyelhetö. Mai napig is számos kérdés merül fel az állati személyiségkutatás terén. Vajon miért alakulnak ki eltérő viselkedésbeli konzisztenciák, akár látszólag előnytelen helyzetekben is? Mi alakítja ki? Mik a háttérmechanizmusok? Mik a potenciálisan rátermettséget jelző egyedi bélyegek (például vannak-e kémiai és vizuális jelzések)? Ezekre a kérdésekre szerettek volna választ kapni HORVÁTH GERGELY és kutatótársai. Vizsgálatuk modellfajaként a KözépSpanyolország magashegyi régióiban honos Iberolacerta cyreni (MÜLLER \& HELMICH, 1937) örvösgyíkfajt választották. A fajról már nagy ismeretanyag gyült össze, több mint 20 éve kutatják. A vizsgálat egyik célja annak tesztelése volt, hogy mi a D-vitamin szerepe az állat kémiai kommunikációjában és szexuális viselkedésében. Vizsgálták a hímek femorális szekrétumát, ami sok információval bír. A provitamin-D a femorális szekrétum egyik kulcsfontosságú összetevője. A kutatási terület 1900 méter tengerszint feletti magasságban terült el a közép-spanyolországi El Ventorrillo kutatóállomáson. A terület nagy részét gránitszikla borítja, és jelentős kiterjedésủ az alkalmas búvóhelynek való növényzet. Egy kamerarendszert állítottak fel és vizsgálták a D3-vitaminnal kezelt és nem kezelt példányok aktivitását és kockázatvállalását. Mérték az előbújási látencia idejét és a harapásra való hajlandóságát (,willingness to bite”). Az eredményeket az „R” statisztikai programcsomag segítségével elemezik, az előadás megtartásakor még a kiértékelés fázisában tartottak. DóZSA-FARKAS KLÁRA: Bizonyított, hogy a nőstények tudják érzékelni a hímek mirigyváladékának szagát? HORVÁTH GERGELY: Igen, ezt a nőstények hímek közelében való nyelvnyújtogatása is alátámasztja. DózSA-FARKAS KLÁRA: Nem lehet, hogy a Dvitamin kiváltja valami más, erősebb anyag kiválasztását? A válasz szerint a folyamat kémiájába nem látnak bele, de ez elviekben lehetséges. Azt már kimutatták, hogy a több Dvitamint allokáló hímek dominánsabbak és jobban vonzódnak hozzájuk a nőstények.

\section{1. előadóülés, 2016. április 6-án}

Az előadóülést NAGY PÉTER elnök úr nyitotta meg és vezette le.

1. BÓNI IMOLA, KISS PÉTER JÁNOS és GALLÉ RÓBERT: A nádasok szerepe a városi izeltlábú diverzitás megörzésében.

Az urbanizáció hatását az ízeltlábúakra számos korábbi kutatás során vizsgálták, melyeket elsősorban az erdő talajfelszínén mozgó faunán végeztek és amelyek szerint ízeltlábú csoportonként jelentősen eltérő hatás mutatható ki.

Előadó és munkatársai vizsgálataik során az urbanizáció hatását tárták fel a nádasokban telelö ízeltlábúak esetén. Szegeden és környékén 16 mintavételi pontot jelöltek ki. A csapdákat mind városon belül, mind pedig a város környéki másodlagos élöhelyeken 4-4 kiterjedtebb nádasba, illetve 4-4 csatornát határoló keskeny nádasba helyezték. Minden kijelölt 
területre egymástól legalább 50 méterre 3x10 telelő csapdát tettek ki, melyek 2015. november elejétől 2016. március elejéig müködtek.

A csapda kialakításának lényege, hogy egy nádat az egyik oldalról nóduszai közvetlen közelében elmetszenek, másik oldalról pedig a nódusz után kis ráhagyással (körülbelül 5 $\mathrm{cm})$ vágják el. Az így kialakult üreg felülről védett és alkalmas ízeltlábúak telelésére. A náddarabokat hurkapálcákra rögzítve helyezték ki a mintavételi helyekre. Február elején a csapdákat kicserélték, így a két időszakban összesen 960 csapdát helyeztek ki, melyekből 795-öt sikerült visszagyüjteni. A csapdák elvesztésének legföbb oka az emberi rongálás volt. Az elfoglalási adatokon végzett tesztek alapján a városon belül található csapdákat jelentősen nagyobb arányban foglalták el, mint a másodlagos élőhelyeken. Ennek alapján, a városon belüli nádasok ízeltlábú faunája nem szegényebb a városon kívülieknél. Az időtartó előadás után kérdések hangzottak el. NAGY PÉTER: Tervezik-e a vizsgálatok megismétlését, majd az eredmények leközlését? A válasz szerint igen, jövőre folytatják, illetve igyekeznek majd publikálni az adataikat. HORNUNG ERZSÉBET javasolta az eredmények másféle elemzését: szerinte nem mintavételi helyekhez rendelve kellene elemezni, hanem azoktól függetlenül, önmagukban. Az ilyen módon kapott mintázat segíthetne hozzárendelni öket az élőhelyekhez (tulajdonképpen lehatárolni azokat). Azt is megkérdezte, milyen ászkákat találtak. A válasz szerint összesen 8 példányt találtak, fajra nem határozták meg őket.

2. CSONKA DiÁNA és HoRnUNG ERzSÉBET: Morfológia és habitat választás, avagy ászkarákok és a kiszáradás.

A szárazföldi ászkarákok az Isopodán belül az Oniscidea alrendbe tartoznak. A csoport szárazföldhöz való adaptációja morfológiai, viselkedési és fiziológiai sajátságokban is megfigyelhetö. Az alaktani jegyek közül a legszembetűnöbb a testméret csökkenése, a pseudotrachea megléte, a zárt költőtáska és a gömbölyödő képesség. SCHMALFuss (1984) nyomán hat ökomorfológiai típust különböztethetünk meg: ezek a „futó”, a „tapadó”, a „gömbölyödő”, a „tüskés”, a „beásó” és a „nem besorolható”. A vizsgálatba igyekeztek e típusok közül többet is bevonni, nyilván az adott területen rendelkezésre álló fauna korlátai között. (Például a „tüskés” alakcsoportba tartozó fajok jórészt trópusi elterjedésűek, így ezek például nem jöttek szóba a tesztelendő fajok között.) A szárazföldi ászkáknál nagyon fontos a kiszáradással szembeni tolerancia, az ászkák sokkal több nedvességet veszítenek, mint például a rovarok. Előadó és munkatársa arra voltak kíváncsiak, hogy a különböző páratartalom értékeken mekkora a deszikkációs súlyvesztés és hogyan alakul a halálozási arány. Feltételezték, hogy a súlyvesztést befolyásolja az egyedek kezdeti tömege, a kültakaró vastagsága és felszíni morfológiája. Mindezt hat fajon tesztelték. Az állatokat elözetesen 100\%-os páratartalmú közegben „telítették” vízzel. Eredményeik szerint 30\%-os páratartalom esetén az Armadillidium vulgare („,gömbölyödő” típus) vízvesztesége és mortalitása volt a legalacsonyabb, a Protracheoniscus politus („futó típus”) értékei pedig a legmagasabbak.

60\%-os páratartalom esetén nem voltak szignifikáns különbségek, míg 100\%-os páratartalom esetén volt a legkisebb a vízveszteség és nem tapasztaltak mortalitást. A tergit vastagsága is az A. vulgare estén volt a legmagasabb. Összefoglalásként Előadó elmondta, hogy a vízvesztés negatívan korrelált a testtömeggel és a kutikula vastagságával. A kiszáradással szembeni tolerancia kompenzálható még felszíni morfológiával, életmóddal, az évszakos vagy napi aktivitási mintázattal. Az előadás után kérdés érkezett Pós ANETTtől: Mennyire elfogadottak az említett ökomorfológiai kategóriák? CSONKA DIÁNA: Teljes mér- 
tékben, mindenki ezeket használja, aki a szárazföldi ászkák kutatásával foglalkozik. SZÖVÉNYI GERGELY a tüskés alakcsoport hiányának okai iránt érdeklődött, illetve a felületi kinövések lehetséges funkcióit hozta szóba. A válaszból megtudhattuk, hogy ezek a fajok főleg trópusi előfordulásúak, a tüskék legfontosabb szerepe pedig ragadozók elleni védelem, a képletek vízháztartási aspektusainak vizsgálatáról nem tudnak. SzÖVÉNYI GERGELY: Mi alapján választották a vizsgált fajokat? CsONKA DIÁNA: Elérhetőségük, gyakoriságuk és talajfelszíni aktivitásuk alapján. NAGY PÉTER: Ez egy elszigetelt vizsgálat volt, vagy valamely tágabb kutatás része. A válasz szerint morfológiai vizsgálatok kiegészítéseként végezték. ban.

3. Korsós ZoltÁn, GARAI CINTIA és OlÁH GYÖRGY: Papagájok és majmok közt Peru-

Az előadást KoRsós ZOLTÁN tartotta. Elmondta, hogy a társzerzők sajnos jelenleg nem tartózkodnak Magyarországon, így nem tudtak eljönni. OLÁH GYÖRGY Ausztráliában van, GARAI CINTIA pedig most épp Torinóban, ahonnan hamarosan Kongóba indul. A kutatóút létrejötte OLÁH GYÖRGY papagájkutatónak köszönhető, aki a Tambopata Research Center irányítója. GARAI CINTIA Kiotóban szerezte meg PhD fokozatát fóemlősök kutatásából. Természetfilmesnek is kiképezte magát, az októberi közös útjukon ő volt a filmes. A 2015. október 8. és 22. között megvalósult kutatóút költségeit a perui állam támogatta. Tambopata az Amazonas síkvidéki erdejének vízgyüjtője. Három kutatóállomás található a területen, ahol a helyi indiánok, a nemzetközi kutatócsoportok és a turisták fordulnak meg. A kutatóállomások önellátó módon müködnek messze a civilizációtól, megközelítésük hajón lehetséges. Előadó és társai a Refugio Amazonas-ba és a Tambopata Research Centerbe látogattak el. Október 8. és 15. között voltak a Refugio Amazonas vendégei. Csónakok segítségével jutottak a szállásokra, ezek viszik egyébként az ellátmányt is. Útközben aranymosókkal találkoztak. Egy fotón, ami az oda úton készült, egy kapibarát láthattunk. A kutatóállomást EDUARDO NYCANDER angol építész (és papagájkutató) álmodta meg. Az épületek szobái az erdő felé nyitottak. Ezután a brazil dió jelentőségéről hallhattunk: szabadon nő az erdőben, az indiánok összegyüjtik és édességet, ízesítőt készítenek belőle, ami később borsos áron exportálásra kerül. Ezután egy zöld lándzsakígyó fotóját láthattuk, majd egy képet a holtágakról, ahol evezni is lehetett. Itt pillantották meg Előadóék a hoacinokat. A hatalmas, a dzsungelben felépített megfigyelőtornyokból (újabb fotó) látni lehet az esőerdő „tetejét”. Ezután állatfotók következtek: aguti, kapucinus majmok és kajmánok, utóbbiakat az esti kirándulás során pillantották meg. Megtudtuk, hogy az Amazonason belül ez az a rész, ahol a papagájok ,,agyagfal nyalogatása” történik. A nyalogatás oka az ásványi anyag pótlás. Az emlősök is végzik ezt a tevékenységet, többek közt a pekarik és egyes ragadozók is. A következő néhány képen gerinctelenek gyüjtése, ostorlábú, valamint ikerszelvényes fajok voltak láthatóak. Előkerült egy Glomeridesmida faj, ami valószínüleg tudományra új, továbbá egy Siphonophorida faj, ami pedig Peru faunájára új. A Refugio Amazonason eltöltött egy hét után a kutatók a Tambopata Research Centerbe utaztak. A vendégek itt kizárólag természetes anyagokból készült tisztálkodó szereket használhattak. Az állomáson a papagájok számára mesterséges odúfészkeket készítettek. Az arák eredetileg óriás odvasfákban fészkelnek, amik sajnos a kivágás áldozatául estek. Fotókat láthattunk a skarlát aráról és a papagájok „nyalogató helyéről”. Hajnalban érkeztek a madarak: először a molnár amazonok, azután a zöldszárnyú arák. Később KORSÓs ZOLTÁN hangfelvételen bemutatta a bőgőmajmok „sugárhajtású repülőgépre” emlékeztető hangját. Pók- 
majmokról és barna kabócamajomról is láthattunk képeket. Mint megtudtuk, utóbbinak madárcsicsergésre emlékeztető hangja van. A folyó mentén tett kisebb kirándulások során a kutatók tapírt, ocelotot, pumát, jaguárt és óriás öves állatot is láttak. A tapírt sikerült lefilmezni, ahogy a vízben úszott. Fájó szívvel búcsúztak Perutól. Az előadás után TÓTH FERENC a „rizseshús fajösszetételét” firtatta. A válasz szerint csirkéből állt. A csirkéket a falvakban tenyésztik. Sertéshússal nem találkoztak az út során.

\section{2. előadóülés, 2016. május 4-én}

A kihelyezett, az MTA ÖK Balatoni Limnológiai Intézetében tartott előadóülést SÁLY PÉTER nyitotta meg, aki üdvözölte a hallgatóságot. Ezután NAGY PÉTER elnök úr röviden bemutatta a Magyar Biológiai Társaság Állattani Szakosztályát.

A szót G.-TÓTH LÁSZLÓ vette át, aki bemutatta az MTA ÖK Balatoni Limnológiai Intézetét, külön kitérve az intézet „,aranykorának” ismertetésére. Az alapítástól a második világháborúig ENTZ GÉZA állt a kutatóállomás élén. Nagyon komoly infrastruktúra állt ekkor rendelkezésre, az erre alapozott (főként faunisztikai és élettani) kutatásaik világszínvonalúak voltak. 1955 és 1962 között WOYNÁROVICH ELEK volt az igazgató, ebben az időszakban a ponty mesterséges szaporítása volt a fó kutatási téma. Ezt követően 1995-ig az eutrofizáció állt a vizsgálatok középpontjában. Napjainkban számos téma köré csoportosulnak a kutatások, a kor kihívásaihoz alkalmazkodva. A bemutatások után a tudományos előadások szekciója vette kezdetét.

1. TÓth MónIKA, MAgYARI EnIKÖ és OlIVER HeIRI: Negyedidőszaki paleolimnológiai vizsgálatok árvaszúnyogok (Diptera: Chironomidae) alapján.

Előadó és munkatársai a Kárpátok és a Balkán negyedidőszaki (kb. 16000 évvel ezelőtti) klímarekonstrukciós kutatását végezték paleo-limnológiai módszerekkel. Egy, a Zürichitóban megtalált, hozzávetőleg 5000 éves nyárfa-ajtó Cladocera, kérész- és tegzeslárva leletei bizonyították, hogy a vizsgált terület végig víz alatt állhatott. Az emberek cölöpházakban élhettek. A tegzesek inkább az ember által lakott időszakokban fordultak elő nagyobb számban, míg a kérészek inkább ezt követően, illetve megelőzően. IndVal elemzés során az emberi hatást türő, illetve arra érzékeny taxonok elkülönítését végezték. DCA elemzéssel az egyes „magok” között markáns változási tendenciák voltak érzékelhetők. Megállapítható, hogy az árvaszúnyog-együttesek jelzései lokálisak (szemben például a pollenekkel), jelentős a cölöpházak árnyékoló hatása. Fentiek azt valószínüsítik, hogy a Zürichi-tónál feltárt neolitkus település(ek) cölöpházakból állt(ak). Az előadás után BOROS GERGÖ feltette a kérdést, hogy mi értelme lehetett a vízre építkezni. A válasz szerint valószínüleg a védelem, de erről még kiterjedt viták folynak.

2. MozsÁr Attila, SÁly PÉter, Antal lászló, Nagy SÁndor Alex és Boros GerGELY: A test szén-, nitrogén- és foszfortartalmának fajon belüli variabilitása és annak ökológiai jelentösége halak példáján.

A kutatók azt vizsgálták, hogy a nitrogén és a foszfor milyen variabilitást mutat egyes halfajokon belül. Ez azért fontos számunkra, mert mindez meghatározza a halak tápanyagforgalomban betöltött szerepét. Az ökológiai sztöchiometria elmélet szerint az eltérő testösszetételü fogyasztók (például halak) által ürített anyagoknak az összetétele (például fosz- 
for-tartalma) is különbözni fog. A Balaton vízoszlopának foszfortartalma felerészben halak testébe zárva helyezkedik el. Ausztráliában rendkívül nagy, robbanásszerü tápanyagfelszabadulás várható. Az elemi összetételt fajon belül körülbelül állandónak tételezték fel, fajok között viszont jelentős különbségeket figyeltek meg. Azóta felmerült, hogy fajokon belül is tekintélyes változatosság lehet (például populációk közötti különbségek). Ezt vizsgálta MozSÁR ATTILA és munkatársai az évszakosság és az ivarok figyelembe vételével a Rakamazi Nagy Morotvában amurgében, naphalon és vörösszárnyú keszegen. Eredményeik szerint meghatározóak voltak a fajon belüli különbségek. Feltételezésük szerint a szén és a nitrogén koncentrációja variábilis, míg a foszforé állandóbb. Meglepő módon azt tapasztalták, hogy foszfor évszakok közötti variabilitása nagyobb, mint a másik két elemé. Lehetséges magyarázat, hogy a foszfor elsősorban a csontokban raktározódik, a zsírok és izmok (mint szén és nitrogén raktárak) jelentős változásokon eshetnek át szezonálisan. Feltételezéseik szerint - az ürített anyagok elemi összetételének direkt vizsgálata hiányában- a halak eltérő elemi összetételü táplálékot fogyasztanak, illetve egyes elemek szelektív visszatartása is lehetséges. Ennek vizsgálata során kiderült, hogy az amurgéb az év során (főleg nyáron) „nitrogén csapdaként” müködik, míg a vörösszárnyú keszeg nitrogénforrást jelent. Azonban a fajon belüli variabilitás túlléphet a fajok közötti különbségeken. E tekintetben különbség mutatkozik az egyes elemekben. Célravezetö lenne párhuzamosan vizsgálni a test és az ürített anyag összetételét.

3. Czeglédi István, SÁly Péter, TakÁcs Péter, Dolezsai AnNa, Vitál Zoltán, NAGY SÁNDOR ALEX és ERŐS TIBOR: Térbeli és időbeli tényezők hatása halegyüttesek szervezödésére kisvizfolyásokban.

A bevezetőből megtudhattuk, hogy a halakat „vándorlási típusok” szerint is csoportosíthatjuk: megkü-lönböztetjük a katadrom halfajokat (mint például az angolnák) és az anadrom fajokat (például tokfélék, lazacok, heringek). CZEGLÉDI IsTVÁN és munkatársai vizsgálták a befolyók szerepét és a vörösiszap katasztrófát követő rekolonizációt. A Marcalba ömlő három kisvízfolyást ellenőriztek: a Sokorói-Bakony-ért, a Gerencét és a Hajagost. Azt találták, hogy a kisvízfolyások kolonizációs potenciálja eltérő, és a kisvízfolyások ökotonként funkcionálnak. Fontos a vándorlási folyamatok jelentőségének kihangsúlyozása, észszerü lenne a halak vándorlási útvonalainak szabaddá tétele. A napszakos különbségek vizsgálatakor sem a torkolati szakaszon, sem fentebb nem találtak különbségeket. Évszakos és szakaszokhoz köthető különbségeket viszont találtak, tavasszal jelentős növekedést észleltek. Szakasz-szinten a torkolat közelében sokkal több egyed volt jelen, mint fentebb. Azt a következtetést vonhatták le mindebből, hogy a kisvízfolyások halegyütteseinek monitorozásában - a nagyobb vízfolyások vizsgálatával szemben - elegendő lehet a nappali mintavételezés is a közösséget jellemző változók reprezentatív becsléséhez. A rekolonizációs vizsgálat során 5 érintett szakaszt ellenőriztek és egyet, ami a befolyó felett volt. Pár héttel a szennyezés után vizsgálták először a kijelölt szakaszokat. A szennyezés után egy évvel a Marcal fajszáma már közelített az azt követő három éves vizsgálat fajszámához. Fontos lehet a refugiumterületek szerepe. Az egyedszám és az abundanciaszerkezet jelentős térbeli és időbeli variabilitást mutatott. A halfajok visszatelepülése igen gyors lehet (akár egy-két év alatt lejátszódhat), ha megvan a lehetôség a rekolonizációra. Jelen kutatások által nem igazolódott az a konzervációbiológiában bevett elv, hogy a bolygatás utáni időszak kedvez az inváziós fajok elszaporodásának. 
4. Preiszner BÁlint, SÜtö Szandra és Szinai PÉTer: Küszvágó csérek (Sterna hirundo) vonulási útvonalának geolokátoros vizsgálata.

A bevezetőben az állatok vonuláskutatásról hallhattunk. A geolokáció a nap-küszöb beállításán alapszik, a dél/éjfél időpontja alapján meghatározható a földrajzi hosszúság, míg a szélesség a nappal/éjszaka hossza alapján. Hozzávetőleg $200 \mathrm{~km}$-es pontossággal „̋őhető be" az egyed tartózkodási helye, de a faj ismerete és a megfelelö kalibráció segíthet mindezt pontosítani. A geolokátorok jelenlegi méretkorlátja kb. 0,6 g, ezt egy 10-12 g-os madárra lehet felhelyezni anélkül, hogy bajt okozna. Ezután Előadó a geolokátor használatának feltételeiről és előnyeiről beszélt, majd jellemezte a küszvágó csért, kiemelve védelmének szempontjait, majd bemutatta a vizsgálat körülményeit. Eredményeik szerint kirajzolódott egy keleti útvonal, ahol a Fekete-tenger és a Boszporusz környéke telelőterületként is szolgálhatott, míg egy másik példány Kenya és Tanzánia felé vette az irányt. A „bakugrásvonulás" oka az interspecifikus kompetíció mértékének csökkentése. Az északabbra költő példányok délebbre vonulnak, „átugorva” a rövidebb vonulási útvonalú „köztes” állományokat. A vizsgálat folytatásaként még több geolokátor felszerelését tervezik, a jövő évtől várható az eredmények megerősítése. Az előadás után a hallgatóság kérdéseket tett fel. NAGY NOÉMI: Mennyibe kerülnek a geolokátorok? A válsaz szerint minimum egy nagyságrenddel drágábbak az egysezrübb GPS-berendezéseknél, tehát 300.000 Ft-ba kerülnek, de azok, amik küldik is az adatokat, körülbelül 1.000 .000 Ft-os áron kaphatóak jelenleg. BoROS GERGÖ: Halakra használható berendezés jelenleg körülbelül 5000 USD áron kapható, és mindössze pár hónapig használható. PREISZNER BÁLINT: „A méret a lényeg”, azaz a miniatürizálás jelentős árdrágító tényező. CZEGLÉDI ISTVÁN: Hogyan fogták be a madarakat a tó közepéröl? A válasz szerint stégeken költő példányokat fogtak be úgynevezett „botlódrótos” fészekcsapdával és mütojásokat is alkalmaztak. SÁLY PÉTER: A vonulási útvonalak partközeli lefutásához kapcsolódóan tette fel a kérdést, hogy a madarak kimenneke a nyílt tengerre. A válasz szerint nem jellemző. A felszín közelében mozgó halakkal táplálkoznak és ezeket inkább a partközeli vizekben találják meg.

Az elöadóülés hivatalos részét SÁLY PÉTER zárta le.

\section{3. előadóülés, 2016. szeptember 16-án}

A Magyar Rovartani Társaság, az Állattani Szakosztály és a Magyar Természettudományi Múzeum közös ünnepi előadóülését NAGY BARNABÁs 95. és MÉSZÁROS ZOLTÁN 80. születésnapja alkalmából tartottuk.

1. Vig KÁRoly: A Magyar Rovartani Társaság köszönti MÉSZÁRos ZolTÁNt és NAGY BARNABÁSt.

Az ünnepelteket elsőként DR. VIG KÁROLY, a Magyar Rovartani Társaság elnöke köszöntötte. Megemlékezett megismerkedésük körülményeiröl és erőt, sok örömöt, egészséget és sikert kívánt, majd egy-egy ünnepi oklevelet nyújtott át DR. NAGY BARNABÁSnak és DR. MÉSZÁROS ZOLTÁNnak, melyeken a róluk elnevezett tarsza- és bagolylepke fajok, valamint egy, az 1940-es években Csepelen megjelent faunára új medvelepke faj láthatóak. Utóbbihoz füződik DR. MÉSZÁROS ZOLTÁN első publikációja. 
2. NAGY PÉTER: Az ünnepeltek köszöntése a Magyar Biológiai Társaság Állattani Szakosztálya részéröl.

Ezután DR. NAGY PÉTER, a Magyar Biológiai Társaság Állattani Szakosztályának elnöke vette át a szót. Elmondta, hogy a két ünnepelt olyan alapon kerülhetett közös ,platformra", hogy mindketten rovarászok, a Rovartani Társaság tiszteletbeli tagjai, mindketten az Állattani Szakosztály aktív tagjai voltak és mindketten igen sokoldalú kutatók. DR NAGY BARNABÁs az Orthopterák kutatásában teljesedett ki, de a Növényvédelmi Intézetben töltött évek alatt sok egyéb taxonnal is foglalkozott. Az Állattani Szakosztályban 50 év alatt 12 előadást tartott. Elöször 1959-ben, amikor DUDICH ENDRE volt a szakosztály elnöke és épp SoÓs LAJOSt köszöntötték 80. születésnapján. Az utóbbi időben majdnem mindig jelen volt az üléseken, kiérdemelné az „Állattani Szakosztály ülések örökös résztvevője” címet.

DR. MÉSZÁROS ZOLTÁN titkári pozíciót is betöltött a szakosztályban. Az évek során hat előadást tartott. Elnök úr mindkét ünnepeltnek sok erőt, békét, szeretetet, egészséget kívánt és egy olyan tájképpel búcsúzott, amely mindkettőjük számára kedves lehet: az erdélyi Szép-havas, háttérben a Gyimes, sok-sok tarszával és lepkével.

\section{Korsós ZolTÁn: A Magyar Természettudományi Múzeum köszönti az ünnepelteket.}

DR. Korsós ZolTÁN, a Magyar Természettudományi Múzeum főigazgatója házigazdaként köszöntötte az ünnepelteket. Elmondta, hogy NAGY BARNABÁs figyelme 1940-ben, egyetemista hallgatóként terelödött az Orthopterák felé. Nemrégiben saját hatalmas gyüjteményét adományozta a múzeumnak, ami 300 rovardoboz több mint 40000 egyenesszárnyú és csótány példányából, valamint 3-4000 fiolányi anyagból áll. Önkéntesként folyamatosan bejár a gyüjteménybe, ahol az adatok digitalizálásán túl a gyüjteményi anyag taxonómiai feldolgozásával foglalkozik. Az ünnepeltnek sok erőt és egészséget kívánt, majd a Magyar Természettudományi Múzeum elismerése jeléül átadta DR. NAGY BARNABÁSnak, mint jelentős gyüjtemény adományozójának a „Pro Studio et Fidei” érmet. Főigazgató úr arról is megemlékezett, hogy DR. MÉSZÁROs ZOLTÁN lepkeadományokkal járult hozzá a múzeum gyüjteményének gyarapításához és egy üveg budai Kadarkával köszöntötte az ünnepeltet.

\section{VARGA ZOLTÁN: Emlékvázlatok hat évtized távlatából.}

Ezután DR. VARGA ZOLTÁN vette át a szót. Elmondta, hogy „emlékfoszlányok” lenne előadása helyes címe, hiszen az emlékek az évek során igen megkoptak. Megtudtuk, hogy Előadót szoros baráti kapcsolat füzte NAGY BARNABÁShoz. Az ünnepelt egyetemi emberként kezdte pályafutását. Egy fiatalokkal foglalkozó egyetemi oktatónak számos rovarcsoporthoz kell értenie: többek között ez volt NAGY BARNABÁs nagy erénye. Klasszikus rovartani alapműveltséggel rendelkezett. Előadó fiatal kutató korában közte és NAGY BARNABÁS között élénk levelezés vette kezdetét, ami ráébresztette VARGA ZOLTÁNt arra, hogy a rovarok közül nem csak a lepkék kutatása tartogat érdekességeket. Előadó aktív, eredményes további éveket kívánt az ünnepeltnek, majd MÉSzÁROS ZoLTÁNhoz szólt. Felidézte egyetemista éveik egyik emlékezetes eseményét. Három rövidnadrágos fiatalember beszélgetett egy szobában: MÉSZÁros ZolTÁN, VARGA ZOLTÁN és VOJNICS ANDRÁS. A diákok éppen azt vitatták meg, hogyan sikerült lepkehálóval begyüjteniük a „canis mergát” lepkék helyett. Jóval később még számos alkalommal összehozta őket az élet, MÉszÁRos ZoLTÁN gyakran vállalta a bírálói szerepet doktori eljárások során Előadó tanszékén. Végül VARGA ZOLTÁN nagy szeretettel köszöntötte MÉSZÁROS ZOLTÁNt születésnapja alkalmából. 


\section{5. ÁBrahÁm LeVEnTE: Prof. Dr. MÉSZÁros ZoLTÁN 80 éves.}

Előadó harminc évvel ezelőtt találkozott először DR. MÉSZÁRos ZoLTÁNnal a Bakonyi Természettudományi Múzeum egyik ismeretterjesztő rovargyüjtö nyílt napján. Nagyon emlékezetes volt ÁBRAHÁM LEVENTE számára, ahogy „MÉzÓ” a maga didaktikus, pedagógus stílusában magyarázott a rovarokról. Ezután életrajzi adatokat tudhattunk meg DR. MÉsZÁROS ZOLTÁNról. 1936-ban született. Nagyapja keltette fel érdeklődését a rovarászat iránt. 1961-ben kertészmérnöki diplomát szerzett, majd két évig szőlőtermesztéssel foglalkozott. 1963-ban került az MTA Növényvédelmi Intézetének identifikációs csoportjába lepidopterológusként. Hamarosan megkezdte a „Növényvédelmi állattan” kurzusok tartását. 1973 és 1975 között feleségével Kubában dolgozott egy növényvédelmi állomáson. 1984 és 1986 között szintén feleségével a magyar-mexikói kukorica programban vettek részt. 1992ben megszerezte a mezögazdasági tudományok doktora címet, majd egyetemi tanárként folytatta pályafutását. 2000-ig a Rovartani Tanszék vezetője volt. 177 tudományos cikk szerzője, számos $\mathrm{PhD}$ dolgozat opponense volt. Az ő nevéhez füződött az Állattani Szakosztály „fiatalok természetismereti klubjának” megalapítása. Számos kitüntetésben részesült, többek között Magister Optima díjban. Ezután Előadó olyan lepkefajokat mutatott be, melyeket DR. MÉSZÁROS ZoLTÁNról nevezett el. Egy genus is őrzi „MÉZÓ” nevét, a délkelet-ázsiai, ausztáliai és pápuai fajokat magában foglaló Maezous nem. Végül DR. ÁBRAHÁM LEVENTE ajándékokkal köszöntötte az ünnepeltet, melyek között szerepelt egy fotó és egy különlenyomat a M. maezus lepkefajról.

6. SZENTESI ÁRPÁD: A tudományos sokféleség dicsérete - pillanatképek NAGY BARNABÁS szakmai munkásságából.

Előadó 1967 végén találkozott elöször NAGY BARNABÁSsal. Akkor éppen a rovarhangok érdekelték, így lett NAGY BARNABÁS szakdolgozója. Két Isophia faj és a keresztezésükből származó utódok hangjának összehasonlítását vizsgálták. Előadó visszaemlékezése szerint NAGY BARNABÁS szobájában egy körülbelül három méter hosszú íróasztal terült el, aminek a környezetében mindenütt ketrecek voltak tele ciripelő Orthopterákkal. Ezen kívül mindenütt hatalmas kupac aktahegyek voltak: a Növénykutató Intézetben NAGY BARNABÁS által vizsgált rovarfajok aktái. Ezek között voltak többek közt Orthopterák, Coleopterák, Hymenopterák, Lepidopterák, és pajzstetvek. A fajok kutatását számos különböző megközelítésben végezték, úgymint radioentomológia, genetikai védekezés vagy autoökológia. 1960 körül volt „divatos” téma a rovarok sterillé tétele. 1966-ban például májusi cserebogáron végeztek egy ilyen irányú kutatást. 53000 hímet gyüjtöttek be, sterilizálták őket, majd kibocsátották. A továbbiakban a pajorok száma csökkent. Később a vizsgálatot babzsizsikkel, almamollyal, szilvamollyal és kukoricamollyal is elvégezték. Kimutatták, hogy a sterilitás - növekvő arányban - az F1 nemzedékben is jelen van. Mindezt a keszthelyi Burgonyabogár Laboratóriumban végezték. A genetikai védekezés terén NAGY BARNABÁs számos külföldi tudományos kapcsolatra tett szert Ausztriában, Kanadában és az Amerikai Egyesült Államokban. Egy másik érdekes kísérlet a kukoricamolyhoz füzödött. A faj őstápnövényei a vadkender és a vadkomló, később váltott át a kukoricára. A faj vizsgálatához a kutatók egy félmesterséges táptalajt dolgoztak ki, ami nagyon bevált. NAGY BARNABÁS, korát megelőzve, a „környezetkímélő biológia” propagálására is nagy hangsúlyt fektetett. 1957-ben jelent meg a témáról egy fontos közleménye A Növényvédelem Idöszerü Kérdései című folyóiratban „A biológiai látásmód fontossága a növények kártevői elleni védekezésben" címmel. A továbbiakban néhány fotót láthattunk NAGY BARNABÁSról a 
„Genetikai Védekezési Konferencián” és a keszthelyi kutatóintézet előtt. Végül Előadó boldog születésnapot és további sikeres sáskavadászatot kívánva köszöntötte az ünnepeltet.

7. SZÖVÉNYI GERGELY és PUSKÁS GELLÉRT: NAGY BARNABÁS, az orthopterológus.

A szerteágazó érdeklődési körü, több taxon terén jeleskedő NAGY BARNABÁs fő kutatási területe az orthopterológia. Mintegy 90 tudományos publikációja, 20 könyvfejezete és 24 ismeretterjesztő cikke jelent meg ebben a témában. Az évek során összegyüjtött egyenesszárnyú gyüjteménye körülbelül 40000 példányt és 3000 fiolát vagy üveget tartalmaz. Tagja a „The Orthopterist's Society”-nek. SzÖVÉNYI GERGELY elmondta, hogy TARTALLY ANDRÁs mutatta be őt egy „bácsinak”, aki élő gyüjteményt is fenntartott. Egy fotót láthattunk a rovartartó ládákról, amikben sok cserép volt elhelyezve, ezekben növekedtek a szöcske és sáska peték, és keltek ki a lárvák. NAGY BARNABÁS „megfertőzte” Előadót az egyenesszárnyúak szeretetével. De vajon hogyan „fertőződhetett meg” ő maga? Debrecenben volt egyetemi hallgató 1942 és 1944 között, majd 1942 és 1944 között Kolozsváron tanult. HANKÓ BÉLA professzor úr karolta fel, és első állása az Állattani Intézetben volt, ahol HERMAN OTTÓ egyenesszárnyú gyüjteményét tanulmányozta. Másik mentora ÖRÖSI PÁL ZOLTÁN méhész volt. Az egyeneszárnyúak kutatásában PONGRÁCZ SÁNDOR volt NAGY BARNABÁS mentora. Nagy hatással volt rá SoÓ REZSÖ korát meghaladó zoocönológiai szemlélete. A második világháború után 1945 és 1946 között NAGY BARNABÁs katonaként hadifogságban volt Dániában és Németországban. Ebből az időszakból is nagy egyenesszárnyú anyag gyült össze. 1946 és 1950 között a Debreceni Egyetemen dolgozott, majd a szocialista éra alatt véget vetettek tanári pályafutásának, így 1950-től a Növényvédelmi Kutatóintézethez került. 2014 óta a Magyar Természettudományi Múzeum Kisebb Rovarrendek Gyüjteményének önkéntese. Eddigi élete során számos témakörben kutatott, úgymint ökológia, táplálkozási vizsgálatok, állatföldrajzi kérdések, urbanizációs kérdések és természetvédelem. Utóbbi a szívügye volt: harcolt a bükki Bélkö bányászata ellen, a mecseki Zengő-hegyen létesítendő NATO lokátor terve ellen, valamint - a csíkosboglárkák védelmében - a tornacsarnok létesítése ellen a Svábhegyen. Ezekhez a témákhoz számos publikációja füződött. Konzervációbiológiai megfigyelések útján részt vett a nemzeti parkok alapállapot felmérésében is. Sok faunisztikai témájú cikke jelent meg, nincs olyan hazai kistáj, ahol ne járt volna. Magyarországon kívül fóként a Kárpát-medence egyéb területein kutatott. Taxonómiával inkább az utóbbi években kezdett el foglalkozni, tudományra új fajokat ír le. 2010-ben együtt írták le Előadóval az Isophya sicula ORCI, SzÖVÉNYI \& NAGY, 2010 fajt. Több egyenesszárnyú faj viseli a nevét, mint például az Isophya nagyi SzÖVÉNYI, PUSKÁS \& ORCI, 2012. Végül SzÖVÉNYI GERGELY egy nagy tarsza fotójával búcsúzott és további sikeres munkát és sok készülő cikket kívánt NAGY BARNABÁSnak.

\section{HALtrich AtTILA: MÉSZÁros ZoltáN a Rovartani Tanszéken.}

DR. MÉSZÁros ZolTÁN 1987 és 2006 között volt a Budapesti Corvinus Egyetem Rovartani Tanszékének munkatársa. Oktatási tevékenysége közé tartozott a „Növényvédelmi állattan" gyakorlat tartása. Ez 2002-ben indult. Akkoriban még nem állt rendelkezésre jegyzet, így a kapott kártevőt a diákoknak le kellett rajzolniuk. „MÉzÓ” érdeme a jegyzetek megszületése. Egyik évben MÉSZÁROS ZOLTÁN teljes féléves oktatását videóra vették, a felvételek szintén hasznos segédanyagnak bizonyultak. Egy fotót láthattunk az első nyárádszeredai végzős évfolyamról. MÉSZÁROS ZOLTÁN nevéhez füződik „A növényvédelmi állattan ökológiai alapjai" címü jegyzet megalkotása, egyes részeit a mai napig is használják az oktatásban. A természetvédelmi szakirányt is ő hozta létre az egyetemen, ez 
2006-ig működött. További képeket láthattunk az ünnepeltről melyek doktori védéseken és rovarász versenyeken készültek. 1989-től kezdve rovarász táborokat tartottak, ezt szintén MÉSZÁROS ZOLTÁN találta ki és 2006-ig ő is vezette őket. A táborozások alatt nappal gyüjtöttek, este pedig lámpáztak. Egy fotót is láthattunk, mely az egyik tábor alkalmával készült a Gyilkos-tónál. Olyan további érdekes gyakorlatokat eszeltek ki a hallgatóknak, mint a „Fantasztikus Live Show”, ahol éjszaka az erdőben élőben figyelhették meg a kis téliaraszolók párzását a fatörzseken. További képeket láthattunk a tanszéki ünnepségekről. HALTRICH ATTILA elmondása szerint ezeken mindig jó volt a hangulat, MÉzó mindenre igent mondott és mindig volt egy-két jó szava az emberekhez. Az ő érdeme a „rovarász majális" létrehozása is, csakúgy, mint a tanszéki lepkegyüjtemény rendbetétele. 1989-ben, 1991-ben és 1994-ben elnyerte a legjobb tanárnak járó „Magister Optimus” díjat. 2010-ben aranydiplomával jutalmazták, majd 2016-ban ezüst fokozatú Életfa Emlékplakettet kapott. Az előadás után MÉSZÁROS ZOLTÁN megköszönte az elismerő szavakat és hangsúlyozta, hogy BALÁZS KLÁRA, JENZER GÁBOR és HALTRICH ATTILA segítsége nélkül mindez nem jöhetett volna létre. MARKÓ VIKTOR hozzátette, hogy MÉSZÁROS ZOLTÁN új lendületet hozott az oktatásba. Rugalmassága, nyitottsága egyértelmüen pozitív hatással volt.

Az ünnepi előadóülés után KORSÓs ZOLTÁN főigazgató úr mindenkit meginvitált egy beszélgetéssel egybekötött zsíros kenyér partyra.

\section{4. előadóülés, 2016. október 5-én}

Az ülést NAGY PÉTER elnök úr nyitotta és köszöntötte a megjelenteket az új „évad” alkalmából. Bemutatta az újrakötött jelenléti könyvet és megkérte a jelenlévőket, hogy aláírásukkal lássák el azt. Ezután köszöntötte a Szakosztály előtt először megszólaló előadókat: BABOCSAY GERGELYt, KONDOR TAMÁSt és BAKONYI ZSUZSANNÁt.

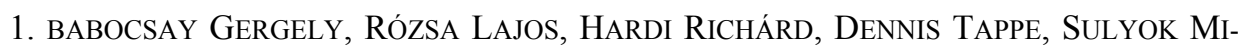
HÁlY és BODÓ IMRE: Az Armillifer pentastomiasis herpetológiai háttere a Kongómedencében.

A bevezetőben a bozóthús fogyasztás problematikájáról hallhattunk. Ennek ugyanis herpetológiai aspektusai is vannak, gondoljunk csak a „herpeto-makrofauna” fogyasztására (gaboni vipera, puffogó vipera, sziklapiton, királypiton). A kutatók ily módon még Kongó faunájára új kígyófajokat is találtak ,,a piacon”. Nemrégiben, 2012-ben, emberi szemből eltávolított „légylárvák” kerültek PAPP LÁSzLÓhoz a Magyar Természettudományi Múzeum Diptera gyüjteményébe. A „légylárvák” valójában Pentastomida-k voltak. Magyarországon akkor még senki nem foglalkozott a csoporttal, ezért RÓzSA LAJOShoz kerültek. Mivel lárvák voltak, nem lehetett őket pontosan meghatározni. HARDI RICHÁRD katolikus misszionárius Kongóban, több magyarországnyi területen dolgozik. Ö a környéken az egyetlen szemészorvos, rengeteg ember látását adja vissza. Ezek után Előadó a Pentastomidák fejlödésmenetét ismertette. A pete mikroszkópikus méretü. A lárva rágcsálókban fejlődik, majd a kifejlett féreg a rágcsálókkal a kígyóba kerülve azok tüdejében élősködik, és rengeteg petét ürít. Az emberek rendszerint köztigazdaként szerepelnek a fejlődésmenetében. HARDI és munkatársai 2013-ban a Clinical Infectious Diseases folyóiratban közölték az esetet, mint ritkaságot. Egy betegből egyetlen példány Pentastomida került 
elő. Egy évvel később SULYOK és munkatársai a PLoS Neglected Tropical Diseases-ben publikáltak a témában. A Pentastomidák nagyon ritkán kerülhetnek a szembe, ez csak ,a jéghegy csúcsa". A leggyakoribbak a tünetmentes (rendszerint nem is diagnosztizált) zsigeri fertőzések. Egy 188 fós mintában a prevalencia 3,7 \%-osnak bizonyult. Kimutattak kettős fertőzéseket is, sőt egy (egyébként gekkókban élősködő) Raillietella faj révén egy személyben hármas fertőzés is kialakult. Genetikailag különböző példányok is előfordultak egy emberben ( 2 faj összesen 5 genetikai változata). Jelenleg egy nagyobb elemszámú kígyóhús minta feldolgozásán dolgoznak. Anekdotikus (néprajzi jellegü) megfigyelések szerint az egész jelenség új, az emlösök és madarak drasztikus egyedszám-csökkenése miatt most kezdenek az emberek ráfanyalodni a kígyók fogyasztására. Egyelöre nem lehet tudni, hogyan terjed át emberre a fertőzés, mert általában nagyon jól átsütik a húst. Talán a konyhai edényekkel, evőeszközökkel. Ennek tisztázásában segíthetne a fertőzés nemek közötti eloszlásának kiderítése. Előfordul-hatnak kevert fertőzések is kígyókban. Az előadás után lehetőség nyílt kérdéseket feltenni. CSONKA DONÁT: Magát a parazitát nem fogyasztják-e el? A válasz szerint az emberek nem, de a kutyáknak odavetik a tisztítás maradékát, így azok vélhetően fogyasztják, azonban állatorvosi vizsgálatok nem ismeretesek erről a területről. KOVÁCS ÁRON: Terraristák között mennyire lehet veszélyes ez a betegség Afrikából behozott kígyókban? BABOCSAY GERGELY: Komoly veszélyekkel járhat, mivel Afrikában számos kígyófarmon dolgozó embernél ez „foglalkozási betegségnek” számít. Másrészt az egyik fajt eleve egy angliai állatkert egyik kígyójából írták le, egy példányról.

2. KONDOR TAMÁS, CSERKÉSZ TAMÁS és FARKAS JÁNOS: Amit sosem mernél megkérdezni - a péniszcsont szerepe (taxonómiai és ökológiai kutatásokban).

Mindenekelőtt az Előadó, KONDOR TAMÁs leszögezte, hogy a címet nem ő találta ki, hanem FARKAS JÁNOS. A „,baculum” szerepének tisztázása előtt körbeadott egy kutya péniszcsontot. Ez föleg ragadozóknál gyakori, a medve-és fókaféléknél extrém nagyméretü lehet. A leggyakrabban azonban néhány milliméter, vagy centiméter méretüek, amelyek kisebb állatoknál fordulnak elő. Majd ezek morfológiai változatainak bemutatására került sor rágcsálók, rovarevők és denevérek esetében. Öt emlőscsoport rendelkezik péniszcsonttal, ezek a ragadozók, a rovarevők, a denevérek, a rágcsálók és a főemlősök. A hat csoport, mely nem rendelkezik baculummal: cetek, patások, nyulak, erszényesek, hiénák és az ember. Felmerül a kérdés, hogy az embernek miért nincs, amikor a többi föemlösnek van? Nem lehet tudni az okát, talán a párzási rendszer megváltozása (poligámiábólmonogámiába). Számos elmélet született változatosságának magyarázatára, mint például a szexuális szelekció, a spermakompetíció (a hosszan elnyúló kopuláció előnyei), a rejtett hölgyválasz (a péniszcsont stimuláló szerepe), vagy a „fegyverkezési verseny” (mennyiség vs. minőség). A „baubellum” vagy „os clitoris”, a baculum-mal homológ csont. A matriarchális szociális rendszerben élö fajok esetében egészen nagyméretü is lehet (pl. Lemur catta). Fosszáknál ismert az „átmeneti maszkulinizáció” jelensége ivaréretlen nőstényeknél. A foltos hiénák hatalmas „,pseudopenis”-szel rendelkeznek (ami szülőcsatornaként is funkcionál), de baubellumuk nincsen. A péniszcsont funkciójára nincs általánosan helytálló válasz, mindig vannak kivételek. Az elfogadottabb elméletek szerint az erekció mechanikai támogatása, a behatolás elősegítése, a nőstény stimulálása, erőteljes mechanikai inger biztosítása és bizonyos fajoknál reflexovuláció (pl. macskáknál, de embernél is lehet ilyen). Mire használható mindez a zoológus kutató számára? Elsősorban rendszerezésre, például földikutyáknál. Az angol nyelvü szakirodalom egyetlen fajt ismer el, de a magyar kutatók 
szerint 3 fajról lehet szó ( $N$. hungaricus, $N$. montanosyrmiensis, $N$. transylvanicus). Ezen kívül kormeghatározásra is szolgálhat: mérete is és csontosodottsága is növekszik a kor elörehaladtával. Az egyed „minőségének” meghatározására is alkalmas: a ,jobb minőségü” egyedeké nagyobb, tömörebb. Mindezek további kérdéseket is felvetnek, az előadás végén ezek közül is áttekintésre került néhány. Búcsúzóul egy az interneten talált baculumnyaklánc fotót láthattunk.

3. BAKONYI GÁBOR és BAKONYI ZSUZSANNA: A pyrausta halála-16-18. századi zoológiai könyvritkaságok és bestsellerek a Pannonhalmi Föapátság könyvtárában.

A Pannonhalmi Főapátság könyvtára Magyarország legrégebbi könyvtára. A ,hiteles helyek" egyike, számos forrás lelöhelye, már a XI. században 80 körüli volt a kézírásos kötetek száma. A XVIII. század végére 4000, jelenleg kb. 400000 kötet található benne. Már a HESS ANDRÁS-féle 1473-as Corvinák között is voltak nyomtatott könyvek. A XVI. század elötti könyvek még nem tekinthetők szaktudományos münek zoológiai szempontból, a korszakot követően pedig már szinte kezelhetetlen mennyiségü volt az irodalom. A föbb források a MOKKA-R és a Karlsruhe Virtual Catalog. Összesen 150 kötet szemlézését végezték el, ebből 36 kötet csak Pannonhalmán található meg. Az 1786-os feloszlatást 1802-ben követte az újraalakítás, erőteljes oktatásra vonatkozó felhangokkal. Az első magyar nyelvü középiskolás tankönyv GÁTI ISTVÁN szerzőségében jelent meg 1975-ben, ez az „Ásványok, plánták és állatok világa”, ,a gyenge elmékhez alkalmaztatva”, még illusztrációk nélkül. Később megjelent GEORG RAFF természethistóriája gyerekeknek (1799) FÁBIÁN JózSEF fordításában, 14 rézmetszettel. Igazi ritkaságok is elökerültek, úgymint: EICHHORN (1891): „Adatok a kicsiny víziállatok természettörténetéhez”, amely már teljesen jól felismerhető Daphnia ábrázolást tartalmazott. Ez sincs meg máshol Magyarországon. Egy másik könyv - a napóleoni háborúk kezdete, illetve a magyar jakobinusok kivégzése idejéből - a „Kanári-kedvelőknek szóló tanítás” (1798), ismeretlen szerző tollából. A „pyrausta halála” szólásmondás azokról az emberekről szól, akik a saját vesztükbe rohannak. „Korabeli bestseller”-nek tekinthető: CONRAD GESSNER (1516-1565) öt kötetes „Historiae Animalium”-a, illetve illetve ULISSE ALDROVANDI (1522-1605) 13 kötetes sorozata, amiből 11 foglalkozik állatokkal. Ezek korukban is drága, nagy ráfordításokkal létrehozott enciklopédikus igényü müvek. Tulajdonképpen a korai újkornak az „internetes keresőmotorjai” voltak. Ezekben a könyvekben már kezdenek megjelenni az igényes ábrák, mint a Bolognai Egyetem honlapján megtalálhatók az ALDROVANDI-ábrák. Ezekből a müvekből maradtak ránk az olyan állatnevek, mint például a „barom bergető”, a „fenebogár”, vagy a „varga légy”: ezek mind a bögölyre utalnak. Ma is visszakereshető a szinonimaszótárból a „,baromkergető fenebogár” fogalma, illetve a „,vargalégy”, mint közönséges marhabagócs (Hypoderma bovis). És hogy mi az oka annak, hogy BAKONYI GÁBORt és ZSUZSANNÁt ilyen mértékben érdeklik a régi könyvek? Többek közt az elődök munkái iránti érdeklődés és a „flow” élmény, a felfedezés élménye: az új megismerése által kiváltott izgalom. 
1035. előadóülés, 2016. november 2-án

A tematikus, az aranysakál hazai kutatása köré szerveződött előadóülést NAGY PÉTER elnök úr nyitotta meg és vezette le.

1. LANSZKI JÓZSEF, KURYS ANITA és NAGYAPÁTI NIKOLETT: Az aranysakál étrendje kutatási tapasztalatok alapján.

Az aranysakál megítélése ellentmondásos, hiszen egyesek kártevő szerepét hangsúlyozzák. Az azonban vitathatatlan, hogy kutatói szemmel nézve a faj igen érdekes. A közelmúltban végzett táplálkozásvizsgálatok csak bizonyos mértékben adhatnak képet a faj étrendjéről, táplálkozási szokásairól. Bizonyos esetekben az aranysakál alaptalanul kerül kártékony szerepbe: az mérgezésben elhullott nagyvadakból olykor az aranysakál táplálkozik és ilyenkor az emberek azt hihetik, hogy az aranysakál ejtette el a vadat. Ugyanez a helyzet akkor is, ha egy gépjármü vadat gázol el. Az aranysakálok nagy arányban zsákmányolnak a hurokba lépett, kerítésbe akadt vagy megsebzett vadakból is, Sokkal hangsúlyosabb azonban eltakarító szerepe. Ez főként a vadzsigerre terjed ki, melyből Magyarországon $33 \mathrm{~kg}$ jut egy négyzetkilométerre, de a lehalászás után visszamaradt haltetemeket is hasznosítja. A szemétevés a hazai állományra nem jellemző, a Balkánon azonban tapasztalták. Háziállatok esetében az okozhat gondot, ha azok őrzéséről, elhelyezéséről nem megfelelően gondoskodnak. Gyakori a predációnak látszó dögevés. Európai viszonylatban elmondható, hogy nincs egyértelmü bizonyíték az aranysakál vadállományt szabályozó képességére. A Somogy-megyében végzett táplálkozás vizsgálatok során azt találták, hogy az aranysakálok változó arányban fogyasztanak kisemlösöket, szarvasféléket, vaddisznót, egyéb állatokat és növényeket. Ezek közül utóbbi két csoport volt a legritkább. A kétújfalui egyedek szőrzetének vizsgálata során megállapították, hogy a sakál jobb minőségü táplálékot fogyasztott, mint a rókák. Extenzív mezőgazdasági területeken a kisemlős, mint táplálékforrás szinte korlátlan mennyiségben áll rendelkezésre. Összegzésként Előadó elmondta, hogy az aranysakál táplálkozási szokásai jelzik a környezet állapotát. Elmondható, hogy a faj opportunista, ami ép rendelkezésre áll, azt eszi. Fontos ökoszisztéma szolgáltatást nyújt a vadzsigerek eltávolításával. Sok még a nyitott kérdés, így a kutatásnak mindenképpen folytatódnia kellene.

2. HeltAI MIKLÓs: Az aranysakál Magyarországon: két évtized tudományos tényei és fontosabb tanulságai.

Előadó egy egyiptomi sakálfejü isten képének bemutatásával kezdi meg előadását. Egy őshonos ragadozó tért nemrégiben vissza Magyarországra. Vajon mi lehet ennek az oka? Hogy közelebb kerüljenek a megoldáshoz, a kutatók sokrétú vizsgálatba kezdtek. Felmérték az aranysakál korábbi elterjedését, genetikai- és rádiótelemetriás vizsgálatokat végeztek. Elöször meg kellett ismerni a fajt ahhoz, hogy jobb képet kaphassanak róla. 1997-ben kezdték meg a vizsgálatokat, melyek legintenzívebben 2001 és 2006 között folytak. Amit a fajról tudunk: évszázadok óta jelen van a Kárpát-medence területén. A 20. század végén terjedésnek indult és eljutott Észtországig, Olaszországig és Svájcig. TóTH és munkatársai (2009) 120 évre visszamenőleg elemezték a hazai aranysakál előfordulási adatokat. Ami szembetűnő: a faj 1995 és 2013 között nagyon elterjedt hazánkban, föként Délnyugat- 
Magyarországon és a Duna-Tisza közén, és folyamatosan tovább terjed, minden irányban. A genetikai vizsgálatok szerint nagy léptékü terjedési modell figyelhető meg, ahol a genetikai diverzitás alacsony. Számos feltételezés született arra vonatkozóan, hogy mi lehet az oka sikerességüknek. A klímamódosulás lehet az egyik ok: a magas, hosszantartó hótakaró hiánya kedvezhetett e rövidlábú faj terjedésének. Egyesek a balkáni háborúkkal hozzák öszszefüggésbe tömeges megjelenését. Az is tény, hogy a faj kiválóan alkalmazkodik a legkülönfélébb élőhelyekhez (erre utalhat a „nádi farkas” elnevezés is). De az aranysakál üldözésének elmaradása (a mérgezések, csapóvasak alkalmazásának megszüntetése) szintén kedvezően hathatott, csakúgy, mint a farkas, mint vetélytárs hiánya. Az akusztikus felmérések azt igazolták, hogy a faj hazánkban stabil állományokkal rendelkezik, de a fluktuáció extrém magas. Folyamatos elterjedés helyett foltszerü elterjedéssel rendelkeznek. Megállapították azt is, hogy a folyóvölgyek szerepe rendkívül nagy a faj migrációs útvonalának tekintetében. 2004 és 2005 között a Tisza mentén figyelték elterjedését, ekkor már ismert volt Somogyban, Baranyában és Bács-Kiskun megyében. Sok kérdés tisztázatlan még a faj táplálkozási szokásairól. Például az, hogy mennyire kiszámítható a táplálékválasztás, illetve adottak-e a közös vadászat lehetőségei. A faj vadászati stratégiáját igen nehéz megfigyelni. A továbbiakban egyéb érdekes eredményekről hallhattunk: hazánkban előkerült egy vemhes szuka, ami valószínúleg kutya-aranysakál hibrid volt. A jelenséget már Horvátországban is kimutatták. Összegzésként elmondható, hogy a faj kutatása izgalmas feladat, sok még benne a lehetőség. Vajon mik az aranysakál terjeszkedésének korlátai? A fajjal kapcsolatos előítéletek és problémák leginkább az ismerethiányból adódnak és abból, hogy az érzelmek és hitek dominálnak a tények helyett. Gyakran egyedi megfigyelésekből vonnak le általános következményeket az emberek. Előadó és kutatótársai komoly publikációs aktivitást fejtettek ki az aranysakál kapcsán: eddigi eredményeik alapján meg lett volna rá minden lehetőség, hogy az illetékesek jó kezelési terveket készítsenek el.

3. NeMESNÉ SOVÁNY KRISZTina és LANSZKi JózSEF: Az aranysakál első GPStelemetriás nyomonkövetésének elözetes tapasztalatai.

Előadó a bevezetőben hangsúlyozza, hogy a ragadozó-ember konfliktus feloldásához fontos, hogy megismerjük az adott fajt. Ennek egy kiváló eszköze a GPS telemetria. Ezt aranysakáloknál jeladós nyakörv formájában alkalmazták. Sok fajon használták már sikeresen a módszert, főként rejtőzködő életmódot folytató állatoknál előnyös. Így nyomon követhető a mozgásuk, vándorlásuk. Európában Magyarországon merült fel elöször az ötlet, hogy aranysakálokon is alkalmazzák a GPS telemetriát. 2013-ban nyakörvet helyeztek fel egy másfél éves, nem szoptató szukára, melyet Zsuzsinak neveztek el. Az állat délkeleti irányban távozott a területről, 2013 novemberében pedig visszahúzódott egy szükebb területre. Decemberben kiterjesztette a területét, aminek egyik lehetséges oka az lehetett, hogy télen kevesebb a rendelkezésre álló táplálék mennyisége, ezért nagyobb területet kell bejárni. Az is lehetséges, hogy a kölykök ekkor mentek el anyjuktól, mely nekiállt új családot alapítani. 2014 januárjában még nagyobb területet járt be. Első útján $42 \mathrm{~km}-\mathrm{t}$ tett meg, amit egy $22 \mathrm{~km}$-es út követett. Ezt követően tizenkét nap alatt 224 kilométert tett meg, majd új területet foglalt és családot alapított. Sikerült nyomon követni a vándorlással telt tizenkét nap eseményeit is: az állat átlagosan naponta $30 \mathrm{~km}$-t tett meg. Minden nap beiktatott pihenő időszakot is és megfigyelhető volt nagyobb- és kisebb léptékủ mozgás is. Délelőtt 10 és délután három óra között volt a legaktívabb, míg éjszaka semmilyen aktivitást nem mutatott. A barrierek és corridorok szerepét is tanulmányozták a kutatók Zsuzsi vándorlása so- 
rán: az állat kétszer is átszelte az M7-es autópályát. A Balaton egyértelműen barrierként szolgált: tél közepén, nagy vízállás idején akadályozta az állat mozgását. Azt is megfigyelték, hogy az állat 200-1000 méternél jobban sosem közelítette meg a településeket. Kóborlása során jellemző volt rá a tisztogatás és dögevés. Zsuzsi április közepéig Somogytúron maradt, majd csatlakozott egy csoporthoz, vagy egy másik egyedhez. Április körül a kotorék körül volt. A nyár a kölyökneveléssel telt. Később Előadó és munkatársai egy másik példányt is jeladós nyakörvvel láttak el. Ez szintén egy másfél év körüli, nem szoptató, segítő státuszú szuka volt, mely október közepétől terjesztette ki az útvonalát.

4. SZABÓ LÁSZLÓ: Az aranysakál akusztikus állományfelmérésének tapasztalatai.

A bevezetőből megtudhattuk, hogy az aranysakál 1989-ben hazánkból kipusztult fajként szerepelt a Vörös Könyvben. Később a faj mégis visszatelepülni látszott Magyarországra. Ez számos kérdést vetett fel. Vajon akkor van, vagy nincs aranysakál hazánkban? Ha van, mekkora az állománya? A kérdések megválaszolásában nyomravezető módszer lehet az akusztikus állományfelmérés. Az aranysakáloknál is alkalmazott módszert HARRINGTON és MECH dolgozták ki és elsőként farkasokon alkalmazták 1972 és 1974 között. Az aranysakálok által kiadott hangok széles tartományban mozognak: jellemző rájuk a vonítás, ugatás, morgás, vakkantás és az üvöltés. Elöadó ezután egy rövid hangfelvételt játszott le: a hallott hangok leginkább majmok „vakkantására” vagy ludak gágogására emlékeztettek. Megtudtuk, hogy az akusztikus felmérés abból áll, hogy a feltételezett aranysakál élőhelyen lejátszanak egy hangot (,provokálás”), amire az állatok válaszolnak. Ez egy gyorsan végezhető, hatékony módszer. Alapja a territoriális viselkedés, a családok közti kommunikáció. Megismerhető így a jelenlét, mód nyílik az állománybecslésre és az állomány változásának nyomon követésére. Azonban ha nincs válasz, az nem jelent feltétlenül hiányt. Két olyan időszak van évente, amikor a legtöbb választ kapják a kutatók: kora tavasszal és nyár végén. Ismét sakál hangokat hallgathattunk meg: egy magányos állat hangját és egy családi vonítást. Ezután megismerhettük az akusztikus felmérés eszközeit. Szükséges hozzá egy kompakt megafon, valamint a hangfelvételhez egy mikrofon és egy digitális hangrögzítő. 100 decibellel érdemes „szólni” az állatokhoz. A felmérés során a kutatók éjszakánként 10-12 pontot vettek fel szél és csapadékmentes időben. Minden ponton háromszor játszották le a hangot, két lejátszás között négy perc szünet volt. Minden esetben feljegyezték a válasz irányát és azt, hogy a válasz magányos (esetleg alfa) egyedtől, vagy családtól származik. 2004 és 2014 között összesen 255 éjszaka végeztek felmérést Somogy, Baranya és Bács-Kiskun megyék területén. Az eredmények szerint a válaszok föként családoktól származtak. Minden évben tavasszal volt nagyobb a pozitív pontok aránya. Arra a kérdésre is választ kerestek, hogy hányszor érdemes lejátszani a hangot: 45\%-ban az első lejátszás után volt válasz. Azt is sikerült rögzíteni (videófelvételen), amikor az állat nem válaszol, de ott van a közelben. A külföldi (görögországi) eredményekkel összhangban, itt is azt kapták, hogy 1000 hektárra kb. három család jut. Az élöhelyvizsgálatok során megfigyelték, hogy az aranysakál hazánkban változatos élőhelytípusokban fordul elő: lápokban, mocsarakban, erdős mezőgazdasági területeken, fás legelőkön, folyami galériaerdőkben, száraz homoki gyepeken, vagy akár a bugaci ősborókásban. Legtöbbször a takarást preferálják. Konklúzióként Előadó elmondta, hogy a módszer hazai adaptációja sikeres volt. A rendszeres családi válaszok stabil családok meglétére engednek következtetni. Egyes területeken extrém magas az egyedsürüség, de ez nagyon változó. 
1036. előadóülés, 2016. december 7-én

Az ülést NAGY PÉTER elnök vezette le. Mindenekelött egy perces néma felállással emlékeztünk meg közelmúltban elhunyt Dr. SzÉKY PÁLról.

1. BAKONYI GÁBOR, KISS IsTVÁN: Megemlékezés Dr. SZÉKY PÁLról (192--2016).

A megemlékezést DR. KISS ISTVÁN tartotta. SzÉKY PÁL 1924. július 29-én született Pécsett. 1938 és 1943 között a Pécsi Püspöki Tanítóképző Főiskolán tanult. Később az Állatorvosi Főiskolán, vagy a Mezőgazdasági Főiskolán szerette volna folytatni tanulmányait, de sajnos nem sikerült bekerülnie egyikre sem, mert a végzettsége nem volt elegendő ezekre a helyekre. Állami szolgálatok sorát vállalta tehát, félévente újabb iskolai tanítói állást vállalt. 1944 és 1948 között a Magyar Agrártudományi Egyetemen hallgatója volt, ahol 1950 és 1955 között tanársegédként, majd 1955 és 1959 között adjunktusként dolgozott. Ezután Gödöllőre került, az Állattani Tanszékre, ahol egyetemi oktatói munkát végzett: többek között gyakorlatokat és előadásokat tartott, a külföldi hallgatók konzultációit vezette és nevelőtanárként is müködött. Első fontosabb könyve a „Halélettan”, ami a halgazdálkodási szakmérnöki képzés tankönyve volt. 1967-ben jelent meg a „A halak élete” címü könyve, mely az első olyan magyar mü volt, ami a halak anatómiáját és élettanát mutatta be. „Állattan" tankönyvei 1965-ben, 1973-ban és 1977-ben jelentek meg. Folyamatos újításokat épített be az oktatástechnikába, ehhez a számos elvégzett tanfolyam adott ihletet számára. Járt többek között fotólaboráns, elektronmikroszkóp, radiológia, anatómia és élettan tanfolyamokra. A tanszéki demonstrációs fejlesztései közé tartozott a folyosó tárolóiban lévő új preparátumok elkészítése, a koponya- és csontvázgyüjtemény, és egy röntgenfelvételgyüjtemény. Ezután egy fotót láthattunk SzÉKY tanár úrról, mint a fiatal kutatók tanszéki mentoráról. 32 tudományos cikk füződik a nevéhez. PhD fokozatát a halak növekedésvizsgálatával szerezte. A biológiai tudományok kandidátusa címet ragadozó kisemlősök morfogenezise témakörben szerezte. 23 könyvet és könyvrészletet és 231 népszerüsítő cikket írt, ezeknek csaknem a fele a Természet Világa magazinban jelent meg. Tagja volt a Pedagógusok Társaságának és a Tudományos Ismeretterjesztő Társaságnak. Hivatása volt az oktatás. Emlékét kegyelettel örizzük.

2. TARTALly ANDRÁs: Mürmekológiai kutatások a Debreceni Egyetem Evolúciós Állattani és Humánbiológiai Tanszékén.

A bevezetőben egy fotót láthatunk a Debreceni Egyetem Evolúciós Állattani és Humánbiológiai Tanszékének folyosóján lévő üveges szekrényről, ami egy mürmekáriumot rejt, ami azt sejteti, hogy ott hangyákat kedvelő kutatók dolgoznak. Előadó elmondta, hogy a hangyák iránti szenvedélye GERALD DURRELL „Amatőr természetbúvár” címü könyvéhez, és az abban látott ábrához nyúlik vissza. Az ábra részletesen bemutatta, hogyan tarthatók otthon hangyák, házilag összeeszkábált tárolóban. Később SzÖVÉNYI GERGELY azt ajánlotta Előadónak, hogy keresse fel ANDRÁSFALVY ANDRÁST, aki köztudottan élő hangyákat tart otthonában. TARTALLY ANDRÁS így is tett, és a találkozóról egy hangyakolóniával tért haza. Később Előadó megismerte GALLÉ LÁSZLÓ tanár urat, aki onnantól kezdve egyengette mürmekológusi pályafutását. Szakdolgozati témája a Lasius neglectus hangyafajhoz kötődött. 5x1 méteres kvadrátokban vizsgálta a szuperkolóniákat. HORNUNG ERZSÉBET közremüködésével hangyavendég ászkákat is vizsgáltak. Később DR. VARGA ZOLTÁN témavezetése mellett dolgozott a Maculinea projecten: a hangyagazdák felmérését, a hangyavendég 
közösség diverzitásának felmérését végezte. Egy másik kutatási területe a Kárpátmedencében és környékén elterjedt tölgyfahangyához kötődött, melynek egyik legnagyobb állománya éppen a debreceni Nagyerdőben van.

3. BÁthori ferenc, Pflieger Walter P., Szentiványi TAMara, FeKete Judit és TARTALLY ANDRÁS: Új rovarektoparazita Laboulbeniales (Ascomycota: Laboulbeniomycetes) fajok a Kárpát-medencére.

Az előadás bevezetéséből megtudtuk, hogy a Laboulbeniales gombarendnek több mint 2000 faja ismert. Obligát ektoparaziták, életciklusuk aszexuális fázisa ismeretlen. Főként Coleoptera gazdafajokkal rendelkeznek és nagy morfológiai változatosság figyelhető meg körükben. Nagyfokú gazdaspecificitás jellemzi öket és elmondható az is, hogy a csoport meglehetösen alulkutatott. Jelenleg hat hangyaparazita Laboulbeniales fajt ismerünk, ebböl négy fordul elő Európában. Ezek közül a legszélesebb elterjedési körrel a Rickia wasmanni faj rendelkezik, míg a másik három faj inkább mediterrán elterjedésü. A Rickia lenoirii faj esetében 44 élőhely 499 Myrmica egyedét vizsgálták, fertőzött egyedek hét élőhelyen fordultak elő. A Laboulbenia formicarum a közelkeletről betelepült invazív fajt, a Lasius neglectust fertőzi. 37 élőhely 4700 egyedét vizsgálták, de gombára utaló nyomot egy egyednél sem találtak. A Laboulbenia camponoti Camponotus hangyafajokon élősködik. 25 élőhely 200 hangya egyedét vizsgálták meg: a gomba több élőhelyről gyüjtött példányokon is előfordult, többek között ausztriai és romániai egyedeken. A Hesperomyces virescens a harlekin katica kutikuláján fertőz. Ez egy nagy, több mint 200 mikrométer nagyságú gombafaj, mely hausztóriumot is növeszt, amivel feltehetően tápanyagokat szipolyoz ki az állatból a kutikulát átütve. A Prolixandromyces triandrus Velia vízipoloska fajokon élősködik. Korábban a jelenség csak Spanyolországból volt ismert. Előadó és munkatársai Herpomyces stylopygae és $H$. ectobiae fajokat azonosítottak laboratóriumi csótánytenyészetekben tartott konyhai- és fakócsótányokon. Az Arthrorhynchus eucamsipodea denevérlegyeken élősködő faj, mely a hazánkban igen ritka hosszúszárnyú denevér légyparazitájáról került elő. Az Előadó konklúzióként azt állapította meg, hogy az említett gombafajok szélesebb körben elterjedtek, mint azt korábban feltételezték. A gomba az entomológusok könynyü célpontja lehet: érdemes nyitott szemmel járni és figyeni a rovarokon a fertőzöttségre utaló jeleket.

4. TARtally András, BÁthori Ferenc és Pflieger Walter P.: Egy Laboulbeniales gombafaj kapcsolata a hangyagazdájával.

A kutatás kezdete 2005-re nyúlik vissza, amikor a Maculineák vizsgálata kapcsán négy Myrmica fajnál találtak gombafertőzött (,szőrös”) példányokat. Annyi tudásuk volt akkor a gombáról, hogy Európa nagy részén ismert, különböző Myrmica fajokat fertőz nagy egyedsürüségben és a fertőzött hangyák képesek sokáig élni. Beadtak a téma kutatására egy Marie Curie ösztöndíjat, amit sikeresen elnyertek. A főbb kérdések a fertözött hangya táplálkozási sajátosságaira, a gomba kapcsolatára a gazdával és a gomba terjedésére irányultak. Transzmissziós elektronmikroszkóp alkalmazásával nem találtak a gombában olyan képletet, ami átüti a kutikukát. Scanning elektronmikroszkópiát használva szintén ezt az eredményt kapták. Felmerült a kérdés, hogy akkor miért alakul ki ez a „fertőzöttség”? A gombát közben hangyavendég zengőlégy lárvákról és atkákról is kimutatták. Lehetséges, hogy a fészekben, mint mikrohabitatban lehet valami a gombák számára fontos dolog, például kipárolgás? Később a kutatócsoport azt tanulmányozta, hogy mit befolyásol a hangyák viselkedésében a gomba jelenléte. Vizsgálták például a vízfogyasztásukat. 12 órán át szom- 
jaztatták a fertőzött és a nem fertőzött egyedeket és azt kapták, hogy a fertőzött példányok sokkal tovább ittak. Tesztelték „bátorságukat” és dominanciájukat is. Előbbit úgy, hogy két eppendorf cső közé egy fekete szívószál darabot helyeztek. A cső egyik végét kinyitották és mérték, hogy mennyi idő alatt jön elő a hangya. A nem fertőzött példányok hamarabb megoldották a feladatot. A dominanciát úgy vizsgálták, hogy egy virágboltban kapható „oázisba" tették a hangyákat és megfigyelték, melyikük kezdeményezi a harcot. A nem fertőzött példányok támadékonyabbak voltak. A továbbiakban a kutatók azt a megfigyelést tették, hogy ha van egy fertőzött kolónia, akkor az összes egyed fertőzött. Tenyésztették a hangyákat és azt találták, hogy ha nem fertőzött kolóniákba helyeztek fertőzött kolóniából származó bábokat, egy vegetációs időszak alatt nem terjedt át a fertőzés. A gombát megpróbálták laboratóriumi körülmények között különbözö táptalajokon tenyészteni, de ez nem járt sikerrel. Négy hétig tartó ezüstkolloidos kezelés után a hangyákról eltünt a gomba. Jelenleg a genetikai vizsgálatok zajlanak. Sok nyitott kérdés maradt továbbra is a témával kapcsolatban. Végül Előadó felhívta a hallgatóság figyelmét arra, hogy a rovarászok járjanak nyitott szemmel, hiszen a vizsgált csoportjaikon is előfordulhat a gomba. Az előadáscsokor után számos kérdést tett fel a hallgatóság. NAGY PÉTER: Mi okozhatta a nagytétényi kolónia öszszeomlását? TARTALLY ANDRÁs: Nem a gombával volt összefüggésben, hiszen azt a hangyafajt nem fertőzte a gomba. Beltenyésztett állományoknál előfordulhat, hogy a „kódját” feltöri egy parazita, ami a szuperkolónia eltủnését okozza. NAGY PÉTER: Vajon használható a gomba rovarkártevők elleni védekezésre? BÁTHORI FERENC: Még az előzőekre reflektálva: nem biztos, hogy a „parazita” kifejezés a legjobb a gombára. Egy osztrák kutatócsoport azt az eredményt kapta, hogy a fertőzött példányok ellenállóbbak voltak rovarpatogénekkel szemben. A gomba-rovar kapcsolatot szimbiózisként kezdték emlegetni. Még nincsenek olyan eredmények, amik azt bizonyítanák, hogy természetes körülmények között is negatív a gomba hangyára gyakorolt hatása (eddig minden vizsgálatuk laboratóriumi körülmények között zajlott). TARTALLY ANDRÁs: Gázkromatográfiás vizsgálat során úgy tủnt, hogy a fertőzött példányok kutikulájában nincs különbség a nem fertőzöttekéhez képest. SzÖVÉNYI GERGELY: Megfigyelték-e, hogy a hangyák kezelik valahogy a testükön lévő gombát? Például megpróbálják leszedni, esetleg eszegetik? TARTALLY ANDRÁs: Ezt a kérdést MARKÓ BÁLINT kutatócsoportja vizsgálja. Az biztos, hogy jobban tisztogatják magukat a hangyák. SZÖVÉNYI GERGELY: De akár meg is ehetik a gombát? TARTALLY ANDRÁs: Nem szedik le, nem kaparják le a gombát. Egyelöre sok a spekuláció és még több a módszertani probléma. NAGY PÉTER: A gomba megjelenése összefüggésben állhat a klimatikus változásokkal? TARTALLY ANDRÁS: Ez egy izgalmas téma és nagy valószínúséggel a helyi mikroklímán is múlhat a fertőzöttség. BÁTHORI FERENC: Sok populáció számos egyedét vizsgálva azt kapták, hogy az adott populáció átlagos fertőzöttségi szintje korrelált a tengerszint feletti magassággal. TARTALLY ANDRÁs: Az is érdekes, hogy a gomba Európa egyes részeiről, mint például Dániából nem ismert, inkább a Mediterráneumban fordul elö. Fejlödéséhez szükséges a pára, a fertőzött populációk mindig valami nagy víz közelében voltak megtalálhatóak.

\section{BABICS JÁNOS és Tóth BALÁzs: (Lepkész) kalandok Dél-Koreában.}

Előadók néhány héttel korábban tértek haza dél-koreai gyüjtő́tjukról. Mint megtudtuk, a repüloút rendben zajlott, de az autóbérléssel akadt némi probléma. A nyelvi akadályokat leküzdve végül sikerült autóhoz jutniuk - még ha nem is olyan típusúhoz, amit eredetileg lefoglaltak - és kezdetét vehette a kaland. A továbbiakban számos fotót láthattunk az észlelt lepke- és egyéb rovarfajokról és ezek élőhelyeiről, a gyüjtőhelyekről, a táborhelyekről, a 
városi látványosságokról és az utazásról. Közben sok érdekességet tudtunk meg a délkoreai népröl: például azt, hogy milyen felfoghatatlan az országot jellemző kettősség: lakói békések, nyugodtak, mosolygósak, de az ország légterében folyamatosan harci gépek gyakorlatoznak és lépten-nyomon szigorúan ellenőrzött katonai erődítmények láthatóak. Ez még fokozottabban észlelhető az ország északi részén, ahol egyértelműen félnek az északi szomszédtól. Az „éjszakai lepkészek” gyüjtési módszereiről is hallhattunk az elöadás során: használnak UV csapdát, esetleg fehér lepedős UV csapdát és vörösboros cukorlébe áztatott spárgát, amit az ágak közt feszítenek ki. Ezekkel a módszerekkel az út során 20 araszolólepkefaj 3-400 példányát, 40-45 bagolylepkefaj 1000-1200 példányát és számos sáska-, poloska- és egyéb rovarfaj egyedeit gyüjtötték be. Az anyag gond nélkül túljutott a repülőtéri ellenőrzésen. Jelenleg a gyüjtött anyag feldolgozása zajlik. NAGY PÉTER: Előadók említették, hogy az ország városokon kívüli területeinek nagy része a nemzeti parkok fennhatósága alá tartozik. Ez nem befolyásolta a gyüjtést? TóTH BALÁzs: A fizetős részekre nem mentek be, ezek határától minimum 1 kilométerre gyüjtöttek. Egyébként a nemzeti parkok területén legálisan el lehet tölteni egy-két éjszakát. 